\title{
The Nexus between Tax Revenue and Economic Growth in Nigeria
}

Edewusi, Damilola Gabriel ${ }^{1}$

Ajayi, Ibidolapo Ezekiel ${ }^{2}$

Department of Finance, Faculty of Management Sciences, Ekiti State University, Ado Ekiti, Nigeria.

Email:ajayidolapo@gmail.com

Licensed:

This work is licensed under a Creative Commons Attribution 4.0 License.

Keywords:

Petroleum profit tax

Companies income tax

Value added tax

Tax system

Economic growth.

Accepted: 27 June 2019

Published: 8 July 2019

\begin{abstract}
This study examined the nexus between tax revenue and economic growth in Nigeria. Specifically, the study evaluated the impact of petroleum profit tax on economic growth of Nigeria, assessed the effect of company income tax on economic growth of Nigeria and ascertained the influence of value added tax on the economic growth of Nigeria. The expost facto research design was employed; time series were collected data from the statistical bulletins of the CBN and the FIRS. The study's model reflected variables including gross domestic product, petroleum profit tax, company income tax and value added tax. Data collated for these variables were analyzed to ascertain the short and long run effect of the variables using the Multiple Regression Analysis, Co-integration and other post estimation tests. Findings from the study indicated petroleum profit tax exerts a positive significant impact on economic growth with a coefficient an estimate coefficient of $3.707601(p=0.5150>0.05)$, company income tax also influences positively and significantly on economic growth with an estimating value of $55.79390(p=0.2580>0.05)$ while the value added tax was also discovered to have a noticeable and positive effect on economic growth with reported coefficient estimates $16.04333(p=0.5949>0.05)$. Following these discoveries, the study advocated that government should make efficacious the tax system of the country so as to curb practices that hampers the effectiveness of the system to generate the required revenue to cause a change in the growth of the economy and modify the institutional arrangement so as to aid a model for best practices of industries in the country.
\end{abstract}

Funding: This study received no specific financial support.

Competing Interests: The authors declare that they have no competing interests.

\section{Introduction}

The most urgent task of governments across nations of the world is to constantly increase the well-being of its people through the activation of necessary economic plans and activities. Governments make all-out efforts in fulfilling this great objective by supplying the public needs such as education, good road, sanitation, security, health-care facilities, electricity etc. The sufficiency of these public goods and services initiates and sustains the growth of an economy (Karumba, 2016). Economic growth has been described as the gradual process by which the productive capability of the economy is heightened over a period of time to cause an increase in the output and income of a nation (Todaro \& Smith, 2006).

The level of growth as well as the changes in the economic growth of any nation is grossly affected by macroeconomic policies including taxation, investment, government expenditure, exchange rate, interest rate and consumption. Tax is conceptualized as a compulsory levy imposed by the government on firms and household (Goode, 1984). Appah (2004) also maintained that tax is a compulsory payment made by a subject or upon his asset to the government for the provision of social amenities, security, ensure a favorable economic position and the wellbeing of the society. Also, indicated in literature are evidences of the capacity of taxation as a tool usable by the government not just to generate revenue, but also to initiate fiscal policy aims that affect strongly the position of investment, control government expenditure, interest rate and create necessary goods and services. Following this, and Anyanwu and Anyanfo (1996) posited that taxes are levies imposed to 
put under control the creation of goods and services, protection of local and small industries, coordinate the affairs of businesses and control inflation etc.

Governments of developed and developing countries are saddled with a crucial role of ensuring a reasonable increase in the growth of the economy over time (Edame \& Okoi, 2014). The achievement of this obligation will not be without the creation of revenue through taxes. Meanwhile, tax rates are as well managed by the government in causing the effectiveness of fiscal policies in any given country; this justifies the connection of tax revenue and economic growth. Approaches by which taxes exert influence on economic growth were described by Tosun and Abizadeh (2005). They maintained that tax rates imposed on corporations, persons and non-inventory assets can impede the level of investment. Again, taxes can decelerate growth in labour supply by removing labour leisure choice in support of labour. Additionally, polices enacted concerning tax exerts significant influence on research and development expenditure. Furthermore, sectors faced with issues of low productivity can be strengthened financially with the revenue generated through taxes. Lastly, increased taxes on labour supply can twist the effectual use of human capital; this is despite the ability tax possesses in breeding high social productivity.

The value added tax (VAT) which replaced the old sales tax in 1994 in Nigeria has prior before its introduction been identified as the main source of revenue in several developing countries. Particularly in Africa, value added tax has maintained 30\% of the aggregate revenue generated (Salizi \& Squire, 1988). On another hand, the petroleum profit tax has accounted for an enormous portion of the inflow realized by the government of Nigeria. This amounted to its largest contribution to the economic growth of Nigeria which possesses an appreciable growth rate of its Gross Domestic Product in Africa. The discovery of oil in the Niger Delta in the 1950's developed the oil industries and made it the major sector of the Nigeria economy (Okoli, Njoku, \& Kaka, 2014).

The report released by the central bank of Nigeria $(\mathrm{CBN})$ as at 2000 and experts in the industry reflects that the revenue created through petroleum profit tax holds over 83 percent of the total revenue generated by the federal government, it also occupies over 40 percent of Nigerian government budgetary revenue (Okoli et al., 2014). The company income tax or corporation tax initiated in 1961 in Nigeria is often charged on the assessable profit of companies operating in the country. The revenue made through this system of tax has been discouraging over time as companies evade the process because they perceive the tax to be discriminating. Also, infant and new industries also get reliefs until reasonable profit is reported. Onaolapo, Fasina, and Adegbite (2013) the tax is condemned because companies considers it a penalty for success without compensation for failure.

The basic idea behind taxation is to create adequate revenue to increase the wellbeing of the people with a particular aim of increasing the position of the economic growth and development. Although reverse has been the case in Nigeria, the economy of Nigeria has stayed in an atrocious state with macroeconomic indicators showing an economy starved of revival, reformation and rejuvenation (Olashore, 1999).

\subsection{Statement of the Problem}

It is a well-known fact that taxes provides most of the government's revenue. But surprisingly, the income realized by the federal government of Nigeria from taxation has over time fallen drastically rendering the government irresponsive to the increasing social and public expenditure necessary for the growth and development of the economy. The prominent issue of creative accounting, tax evasion and avoidance has been accommodated due to the inefficiency of Nigerian tax system (Ayua, 1996). This has persistently caused a total inefficiency and defects affecting negatively the income reached from taxes during the past few years and consequently, an unpleasant economic growth.

The amateurish character of the Federal Inland Revenue Service Board in Nigeria has not eased the problem as they have in their acts been unable to capture in their tax net, all corporations operating in the country. Also evident in the structure of tax in Nigeria are issues related to dearth of data, corrupt practices and an unorganized monitoring and enforcement approach (Leyira, Chukwuma, \& Asian, 2012). As a result of these, the economic state of the nation has remained discouraging leading to the bankruptcy of several businesses. This is despite the large population and the largest economy it maintains Africa. As at 2015, the petroleum profit tax reduced by $55 \%$ in contrast to the previous year, company income tax increased marginally by $4 \%$ and value added tax dwindled to about less than $21 \%$ of its position in the previous year, all of these unpleasant report has placed Nigeria's economy in an unpleasant position.

The economy is dwindling day by day, institutions are performing poorly due to the unsuitable state of transportation, politics, power and financial system. In fact, the investigation of the EIA (2015) reported that the electrification rate in Nigeria is assessed to be $41 \%$ inflicting darkness on approximately 100 million people in the country. Iweala (2013) maintained that about $75 \%$ registered firms are not found in the tax net of the country and $65 \%$ of them had not filed their tax returns for over 2 years. This according to her resulted in a loss of over 8obillion worth of naira leaving the revenue realized in that period to about \$250million. This despicable report is too bad to be accepted. On this ground, this study sets out to examine the nexus between tax revenue and economic growth in Nigeria. 


\subsection{Objectives of the Study}

The main thrust of this study is to examine the nexus between tax revenue and economic growth in Nigeria. The study will specifically:

i. Evaluate the impact of petroleum profit tax on economic growth of Nigeria

ii. Assess the effect of company income tax on economic growth of Nigeria.

iii. Ascertain the influence of value added tax on the economic growth of Nigeria.

\subsection{Scope of the Study}

The research in its quest to evaluate the relationship between tax revenue and economic growth covers a period of twenty years (1995-2015).

\section{Literature Review}

2.1. Taxation

Tax is a non-punishing but compulsory transfer of resources from the public sector to the private sector imposed on individual's personal income, corporations and institutions without recourse for immediate benefits for the tax paid (Ofishe, 2015). The concept is also referred to as a compulsory transfer of resources to the government from other systems (World Bank, 2000). Adeyeye (2004) maintained that tax is a liability on account of taxpayer as a reasonable contribution to the available fund required for use by government in providing necessary infrastructure for her citizens. Meanwhile, Miller and Oats (2006) described tax as the statutorily compulsory determinable amount required by a legal authority from the productive activities of a person or corporate body for the provision of public goods and services.

\subsection{Economic Growth}

Economic growth is conceptualized as the continuous increase in the per capita national product or net national period over a long period of time (Dwivedi, 2004). This suggests that the speed at which the total output increases must be greater than the speed at which population increases. Igbasan (2017) clarified that another measure of economic growth is that national product should comprise of goods and services that meets the urgent need of a reasonable number of people. He also maintained that economic growth can be ascertained by four important indicators such as national resources, human resources, technological development and capital formation.

\subsection{The Nigeria Tax System}

The political environment of Nigeria accepts the federal system of governance; following this, her fiscal activities adopts the same principle which results in a serious consequences on the tax management system in use in the country (Odusola, 2006). The fiscal policy of governments of countries using a three tier tax system i.e. Federal, State and Local Governments with their respective tax jurisdiction (Enahoro \& Olabisi, 2012).

The Nigerian tax system is typical of distortion, avoidable complexity and almost full of inequitable tax laws that have restricted application in the informal sector that dominates the economy (Odusola, 2006). Abubakar (2008) opined that the Nigerian ta system has been through several unusual changes in the past years. The tax system is the process of taxation which includes a number of rules, procedures and regulations with the organs of administration mixed with one another to create fund for government (Abegunde, 2010). The system of tax in use in Nigeria involves several activities inlaying tax laws, tax administration and tax policies (Adesola, 2004).

The existing Nigerian law states that taxation is enforced by the three tiers of government i.e. federal government, state government and local government with each government possessing authority clearly stated in the taxes and levies Act, 1998 (Abubakar, 2008). Naiyeju (2010) and Odusola (2006) premised their argument concerning the Nigeria tax arrangement, they posited that the system is tilting and relies mainly on oil revenue.

Tax administration has over time been ineffective; this has formed the base for the low tax revenue (Garde, 2004). He also opined that the abominable tax collection is a function of the performance of the tax administration and public service in Nigeria. The broad aim of every tax system particularly Nigeria is to appropriately utilize revenue for the nation's growth and development. As indicated by the presidential committee on National Tax Policy (2008) the main objectives of the Nigeria tax policy are to contribute to the welfare of the people indirectly through the appropriate usage of tax revenue and to make provision for the welfare of the people directly through enhanced policy formulation.

\subsection{Revenue Generation in Nigeria}

The development of any country relies greatly on the capacity of the government in creating revenue for the supply of adequate infrastructural facilities (Appah, 2010). Nigeria generates revenue from several sources including the internal and external sources. The internal sources of revenue according to Worlu and Emeka (2012) is classified into the oil revenue (including royalties, petroleum profit tax, gas tax) and the non-oil revenue (including direct and indirect tax, loans, grants, trades, aids). 
Nigeria has since her discovery of oil in 1973/1974 neglected completely other sources capable of creating revenue for the government (Odusola, 2006). In fact, over $70 \%$ of the country's realized revenue comes from the oil sector (Igbasan, 2017). Despite this, the existence of oil theft, international politics, price fluctuation, militancy in the Niger Delta, insecurity and unending corrupt practices in the system has hampered the level of revenue inflow from the oil sector causing a total neglect of the demand for public goods and services. This calls for a complete development of Nigeria tax administrative system to further enhance tax revenue in the country (Worlu \& Emeka, 2012).

\subsection{Causes of Inadequacy of Tax Revenue}

The reason for the inadequacy of tax revenue created in Nigeria is due to many different factors including dearth of statistical data, unimpressive tax administration, double taxation, inability to prioritize tax effort and endemic corruption (Leyira et al., 2012). Ayodele (2006) asserted that the neglect of the non-oil revenue despite its potential to create great tax revenue inflow has also contributed to the inadequacy of tax revenue in Nigeria.

Again, the existence of tax evasion, increased cost of compliance and the ambiguity of tax laws were also discovered as some other factors that has contributed to this menace (Uremadu \& Ndulue, 2011). Leyira et al. (2012) affirmed that the situation and scope of a nation's tax system must be ascertained before it can operate a suitable tax system. Such tax system must be cheering to aid easy compliance, treat taxpayers as partners, reward frequent compliance, strong willed and legally enforces compliance, complete orientation of tax payers and perform its functions transparently (Adegbie \& Fakile, 2011; Edemode, 2009).

\subsection{The Relationship between Taxation and Economic Growth}

The tax system of every nation grossly influences other macroeconomic variables. This fact tends to be more evident amongst the developed and developing countries. It is show in the literature that the height of economic development exerts a noticeable effect on the tax base of a country and tax policy objectives changes as the level of development changes (Kiabel \& Nwokah, 2009).

Tax policies affects significantly economic ability at the micro and macro level, this necessitates a critical stabilization tool for economic policymakers. In any nation, the quantity of tax revenue will influence strongly people's economic behaviour including their choices of saving, working and investing, this goes a long way in positioning the economy of the country (Ola, 2001). Also, increased tax revenue does not only inflate the cost of individual's welfare but also affect immensely consumer expenses through reduction of the disposable income (Adereti, Sanni, \& Adesina, 2011).

Nigeria in terms of GDP as at 2011 maintained the $30^{\text {th }}$ position in the world (Wikipedia - The Free Encyclopedia, 2011). This indicates that as a developing country, it can still harness every alternative to increase its revenue and increase its rank in the world. Nigeria is at present ranked the third largest economy in Africa considering its wide national output, with adequate arrangement; it can become the $20^{\text {th }}$ largest economy in the world by 2025 .

It has been maintained that the level of spending in any economy is influenced by the level of revenue created through tax (Inglehart, Foa, Peterson, \& Welzel, 2002). An increased tax burden exerts a strong effect on the overall economy. Adereti et al. (2011) asserted that the fact in numerous developing nations is that while there is much budgetary arm-twisting stemming from the increasing request for government spending, there is a less opportunity for increasing tax revenue. Several tools usable to create enough revenue through tax exists within the reach of the government, these tax instruments includes corporation and personal taxes, value added taxes, custom and excise duties, capital gain tax, withholding tax etc (Desai, Foley, \& Hines, 2004). The current liberation plan of the Nigerian economy instigated by the Federal Government indicates that the country is becoming a safe place for investment despite the frequent blows the economy has suffered (Unegbu \& Irefin, 2011). In all, tax revenue is extremely important to the growth and development of any country as tax revenue enhances the rural and urban development.

\section{Theoretical Framework}

\subsection{Traditional Tax Handle Theory}

The traditional tax handle was postulated by Solow (1956) and Swan (1956). They posited that the level of fiscal need is nearly related to the level of economy development (Musgrave, 1989). According to this theory, to reach a certain level of growth of per capita income, there is need to create a given level of national income through taxes.

Taxes are obligatory contribution for which no certain benefit is received in return to the tax paper. Taxes are arranged to compulsorily make the household to transfer the purchasing power to the government for its use. The process also affects significantly the allocation of resources, recognize social costs which are not evident in the market prices and affect the allocation of income and wealth since they reduce the disposable income and wealth to those who bear them (Goode, 1984).

Mansfield (1998) is one of the leading proponents of the tax handle theory as being the most important theory that describes the approach of tax structure in the developed and developing countries. The theory suggests that as a country's per capita income and level of monetization increases, indirect taxes becomes more 
noticeable more than direct taxes. Therefore, while direct taxes contribute significantly to the fiscal revenues of developed countries, the indirect taxes contribute much more to the growth of the developing countries (Karumba, 2016).

\subsection{Empirical Issues \\ 3.2.1. Evidence from Nigeria}

Abomaye-Nimenibo, Michael, and Friday (2018) empirically assessed the relationship between tax revenue and economic growth in Nigeria. The study centering on data spanning 1980-2015 particularly examined the relationship between petroleum profit tax and economic growth in Nigeria, assessed the relationship between company income tax and economic growth in Nigeria and analyzed the relationship between custom and excise duties and economic growth in Nigeria. The authors employed a quasiexperimental research method, included in the variables in the study's model are petroleum profit tax (PPT), company income tax (CIT) and Customs and Excise Duties (CED). Secondary data spanning 1980-2015 for the identified variables were retrieved from various issues of the CBN statistical bulletin and analyses including Ordinary Least Square (OLS), Co-Integration and Granger Causality test were conducted. Discoveries evident in the study revealed that there was a long-run relationship among the variables; it was also revealed that Petroleum Profit Tax and Company Income Tax has no significant relationship with economic growth in Nigeria, although custom and excise duties was found to significantly affect economic growth in Nigeria. Following these findings, the study recommended that government should also make it impossible for companies to evade tax and penalize any company that have registered but evades tax payment.

Ojong, Anthony, and Arikpo (2016) evaluated the impact of tax revenue and economic growth in Nigeria. Specifically, the research examined the relationship between petroleum profit tax and the Nigerian economy, ascertained the effectiveness of company income tax on the Nigerian economy and examine the Impact of Personal Income tax on the Nigerian economy. The study used the exploratory and ex-post facto research design and time series data spanning 1986-2010 were gathered from a secondary source - CBN statistical bulletin. Variables indicated in its model include company income tax, non-oil revenue, petroleum profit tax and gross domestic product, the OLS multiple regression was employed in analyzing the relationship between the variables. It was discovered that there exists a noticeable connection between petroleum profit tax and the growth of the Nigeria economy, it was also indicated in the findings that there is no significant relationship between company income tax and the growth of the Nigeria economy. The study suggested that government should endeavor to provide social amenities to all nooks and crannies of the country and that government should engage in a complete re-organization of the tax administrative machineries.

Yahaya and Bakare (2018) assessed the effect of petroleum profit tax and companies income tax on economic growth in Nigeria. The study alongside its main objectives also examined the effect of petroleum profit tax on gross domestic product in Nigeria and assessed the effect of company income tax on gross domestic product in Nigeria. The time series research design is employed in the research. Secondary data spanning 34 years (1981-2014) were sourced from the Federal Inland Revenue Service (FIRS) and the Central Bank of Nigeria (CBN) statistical bulletin 2014. The study ensured a robustness in its assessment as it include in its model variables including company income tax, petroleum profit tax, custom excise duties and gross domestic product. The fully modified least square regression technique, Augmented Dicker Fuller, unit root test and co-integration test was used in analyzing data retrieved in the study. The study discovered that that petroleum profit tax (PPT) and company income tax (CIT) have positive significant impact on gross domestic product (GDP) in Nigeria. Premise on the findings, the study suggested among others that government should transparently and judiciously account for the revenue it generates through petroleum profit tax by investing in the provision of infrastructural facilities and Revenue accrue to government through PPT and CIT should be judiciously used to develop the economy.

Edame and Okoi (2014) evaluated the impact of taxation on investment and economic development in Nigeria. The study in particular examined the impact of taxation on investment in Nigeria, investigated if there are any contributions of tax to real gross domestic product (RGDP) in Nigeria and determined whether the extent of cross sectional allocation of resources through tax revenue has impacted the level of investment in Nigeria. Secondary data for company income tax, personal income tax, gross domestic product, investment level in Nigeria and government expenditure were sourced from the chartered institute of taxation of Nigeria CITN (Annual Journal), Central Bank of Nigeria statistical bulletin (CBN), NBS and published data from the federal ministry of finance. Data retrieved in the study were analyzed using the ordinary least square of multiple regression. The research discovered that an inverse relationship exist between taxation and investment i.e. one percent (1\%) increase in CIT will result in decrease in the level of investment in Nigeria and an increase in PIT will result in decrease in the level of investment, it was also realized that taxation statistically is significant factor influencing investment, GDP and government expenditure in Nigeria. The authors suggested that the government of Nigeria should use taxation to achieve its set target that will enhance economic growth and development.

Egbunike, Emudainohwo, and Gunardi (2018) assessed the effect of tax revenue on the economic growth of Nigeria and Ghana. The study specifically determined whether there is a positive effect of tax revenue on the gross domestic product of Nigeria and determined whether there is a positive effect of tax revenue on the 
gross domestic product of Ghana. Secondary data spanning 17 years (2000-2016) were gathered from the Central Bank of Nigeria Statistical Bulletin and Bank of Ghana Statistical Bulletin. The study employed the granger causality and multiple regressions in analyzing data collate in the study. Findings discovered in the study showed that a positive impact of tax revenue on the gross domestic product of Nigeria and Ghana confirming prior studies. Based on the author's discovery, they among others recommended that adequate measure to ensure that revenue generated from the tax is effectively utilized to develop and grow the economy.

Ogundana, Ogundana, Ogundana, Ibidunni, and Adetoyinbo (2017) examined the impact of direct and indirect tax on the Nigerian economic growth. The study particularly assessed the trend of direct tax and its components, indirect tax and its components, and economic growth of Nigeria and determined the impact of direct tax (Company Income Tax (CIT) and Petroleum Profit Tax (PPT)) and indirect tax (Customs excise duties (CED), and Value added tax (VAT)) on Nigerian economic growth. The descriptive research design was adopted in the study and secondary data in the period of 1994-2013 concerning these variables were gathered from the Central Bank of Nigeria $(\mathrm{CBN})$ statistical bulletin and annual report for several years. The authors employed the trend analysis and the OLS regression techniques in reaching the study's analysis. It was realized that the direct and indirect tax have a positive impact on the economy of Nigeria. Hence, the study recommended that government should harness the potentials of taxation and also promote tax system in order to increase the prosperity of Nigeria's economy.

Onakoya and Afintinni (2016) evaluated the relationship between taxation and economic growth in Nigeria. The particular concern of the research was to determine the impact of petroleum profit tax, company income tax, personal income tax and value added tax revenue on Nigeria's Economic growth. Secondary data spanning thirty years (1980-2013) were retrieved from the Central Bank of Nigeria (2014) and the National Bureau of Statistics (2014). Numerous analysis including descriptive statistics, augmented dickey fuller (ADF), co-integration test and vector error correction model were used in analysis the study's data. The research discovered that a long run (but no short run) relationship existed between taxation and economic growth in Nigeria. It was also obvious from the result that a significant positive relationship at $5 \%$ level of significance between Petroleum profit tax, Company Income tax and economic growth, but a negative relationship between economic growth and customs and Excise Duties. Following these findings the study advocated that strong institutional reforms should be caused in the Department of Customs in order to plug the manifest leakages; ax collection mechanism used by tax officials must be free from corruption and embezzlement and the federal government, state governments and local governments should urgently modernize and automate all its tax system.

\subsection{Evidence from Developing Countries}

Karumba (2016) examined the impact of taxation on economic growth in Kenya. The study focusing on the tax and economic activities between 1975-2014 specifically identified the impact of taxes on economic growth. The research employed an econometric model and captured variables including indirect tax, direct tax, other taxes, interest rates, foreign direct investment, net export and gross domestic product. It employed the ordinary least square method and other pre-estimation tests in conducting its analysis. Results revealed that 96.8 percent of the variation in GDP is explained by indirect taxes, direct taxes, other taxes, interest rate, foreign direct investment and net exports, also evident in the discoveries of the study is that the coefficient of indirect taxes was negative and individually significant in influencing the economic growth in Kenya in the short run and the coefficients of FDI and net exports were revealed to be positive and separately significant in affecting the economic growth in Kenya in the short run. The author recommended that policy makers should focus more on how to enhance international relations in order to attract FDI and also enhance export promotion.

Nkhalamo and Sheefeni (2017) examined the connection between tax and economic growth in Namibia. The study using quarterly data sourced from the ministry of finance, Namibian statistical agency and Bank of Namibia publication focused on tax and economic activities for the period 2001-2005. Results reported by the study reflects that no long run relationship exists between tax and economic growth in Namibia, further results aimed at analyzing the short run effect of the independent variable revealed that an immediate negative effect of tax exists on economic growth resulting from shocks in tax and more importantly the forecast error variance decomposition revealed that tax is responsible for moderate fluctuation in economic growth in Namibia. Considering the findings, the study recommended that the government should adopt the progressive type of tax and increase tax administration to increase efficiency, and increase investment through reduction of taxes.

Maqbool, Shahzad, and Nisae (2016) empirically investigated the relationship between taxes and economic growth of Pakistan. Specifically, the study determined the influence of total taxes in the long and short run period and investigated the impact of total taxes on economic growth. Time series data relating to tax returns and gross domestic growth spanning 37 years (1974-2010) were collated from the Economic Surveys of Pakistan and handbook of Statistics on Pakistan's economy (SBP). The research in its quest to ascertain the long run and short run relationship between the variables employed the Auto Regressive Distributed Lag (ARDL) approach of co-integration. The study's result revealed that Total tax revenues in the long run have 
negative and significant effect, on economic growth, in the ort run, impact of total taxes on economic growth is insignificant. The study advocated that indirect taxes should be reduced, to increase economic growth.

Lerato (2016) assessed the relationship between tax and economic growth in South Africa. Specifically, the study assessed the impact of different types of tax (PIT, CIT and VAT) on economic growth in South Africa. The quantitative research design was employed as quarterly secondary data covering the period of 2003-2016. The autoregressive distributed lag (ARDL) co-integration framework was employed in analyzing data collated in the study. Results obtained in the study revealed that a positive relationship exists between taxes and growth, where increases in VAT lead to increases in growth and increases in PIT and CIT are stimulated by economic growth. The study therefore suggested that there rather be an increase in VAT as opposed to the other tax types so as to bring about a more impactful, positive increase in economic growth.

\section{Methodology}

The ex-post facto research design was adopted in obtaining time series data from the statistical releases of the Central Bank of Nigeria (CBN) and the Federal Inland Revenue Service (FIRS). Data required for this study are secondary time series data regarding the dependent and independent variables spanning twenty years (1995-2015).

\subsection{Model Specification}

In our desire to examine the nexus between tax revenue and economic growth in Nigeria, a multiple linear model is created. The model which is a replica of the broad and specific objectives of the study captures the contribution of petroleum profit tax, company income tax and value added tax to GDP. This is indicated in the functions below:

$$
\mathrm{GDP}=f(\mathrm{PPT}, \mathrm{CIT}, \mathrm{VAT})
$$

From the above linear specification, the statistical model was originated.

$$
\mathrm{GDP}=\alpha+\beta 1 \mathrm{PPTt}+\beta 2 \mathrm{CITt}+\beta 3 \mathrm{VATt}+\varepsilon
$$

The linear function (1) was changed into their lag form in order to make our results more interpretable as well as meet the basic assumptions of inferential statistics. Hence, we have:

$$
\text { GDP }=\alpha+\beta_{1} \text { LPPT }+\beta_{2} \text { LCIT }+\beta_{3} \text { LVAT }+\varepsilon
$$

Where;

GDP $=$ Gross Domestic Product, PPT $=$ Petroleum Profit Tax, CIT = Company Income Tax

VAT: Value Added Tax

$\alpha$ is a constant

\subsection{Presentation of Results and Discussion}

This section focuses on the presentation, analysis, interpretation and discussion of findings. The empirical results based on the specified models in the previous section are presented, while the interpretation and discussion of each result is related to the justification of the stated objectives.

\begin{tabular}{c|c|c|c|c}
\multicolumn{7}{c}{ Table-4.1. Descriptive Statistics. } \\
\hline GDP & PPT & CIT & VAT \\
\hline Mean & 28805474 & 1255173. & 370615.6 & 308126.7 \\
\hline Median & 14610881 & 1097945. & 140300.0 & 178100.0 \\
\hline Maximum & 89043615 & 3201319. & 1229017. & 802964.6 \\
\hline Minimum & 2907358. & 42858.00 & 21878.00 & 20761.00 \\
\hline Std. Dev. & 30188650 & 1033100. & 402018.6 & 281855.8 \\
\hline Skewness & 0.945889 & 0.449272 & 0.940959 & 0.594883 \\
\hline Kurtosis & 2.248263 & 1.972791 & 2.528540 & 1.795926 \\
\hline Jarque-Bera & 3.625938 & 1.629722 & 3.293401 & 2.507172 \\
\hline Probability & 0.163169 & 0.442701 & 0.192685 & 0.285479 \\
\hline Sum & $6.05 \mathrm{E}+08$ & 26358628 & 7782928. & 6470660. \\
\hline Sum Sq. Dev. & $1.82 \mathrm{E}+16$ & $2.13 \mathrm{E}+13$ & $3.23 \mathrm{E}+12$ & $1.59 \mathrm{E}+12$ \\
\hline Observations & 21 & 21 & 21 & 21 \\
\hline
\end{tabular}

The descriptive statistics presented in Table 4.1 revealed that the average gross domestic product, petroleum profit tax, company income tax including value added tax for the period covered in the study stood at $28805474,1255173,370615.6,308126.7$, respectively. The above table also reported maximum and minimum values of 89043615 and 2907358 for gross domestic product, 3201319 and 42858.00 for petroleum profit tax, 1229017 and 21878.00 for company income tax and 802964.6 and 20761.00 for value added tax respectively. Furthermore, the table revealed that all the variables used in the study are positively skewed with specific skewness statistics of $0.945889,0.449272$, 0.940959 , 0.594883 for gross domestic product, petroleum profit tax, company income tax as well as value added tax. Kurtosis statistics reported in Table 4.1 revealed that all the variables used the study are platykurtic with specific kurtosis statistics of 2.248263, 1.972791, 
2.528540, 1.795926 for the respective variables. Jarque-bera statistics reported in Table 4.1 revealed that all variables are near normal distribution given their corresponding probability values that are considerably high to guarantee an acceptance of the normality hypothesis that the reported jarque-bera statistics are not significantly different from zero.

\begin{tabular}{c|c|c|c|c}
\multicolumn{5}{c}{ Table-4.2. Correlation Matrix. } \\
\hline Variables & GDP & PPT & CIT & VAT \\
\hline GDP & 1.000000 & & & \\
\hline PPT & 0.754612 & 1.000000 & & \\
\hline CIT & 0.972624 & 0.679211 & 1.000000 & \\
\hline VAT & 0.965580 & 0.821685 & 0.957652 & 1.000000 \\
\hline
\end{tabular}

\subsection{Correlation Analysis}

Table 4.2 presents the correlation coefficient for pairs of variables used in the study. Specifically the table reported correlation statistics of $0.754612,0.972624,0.965580,0.679211,0.821685$ and 0.957652 for GDP and PPT, GDP and CIT, GDP and VAT respectively. The result revealed that there is strong positive relationship between pairs of all variables used in the study, meaning the pairs of variables moves in the same direction.

Table-4.3. Summary of Unit Root Test Result.

\begin{tabular}{c|c|c|c|c|c|c|c}
\hline \multicolumn{4}{c|}{ At Level } & \multicolumn{4}{c}{ At First Difference } \\
\hline Variables & $\begin{array}{c}\text { ADF } \\
\text { statistics }\end{array}$ & $\begin{array}{c}\mathbf{1} \% \\
\text { critical } \\
\text { value }\end{array}$ & $\begin{array}{c}\mathbf{5 \%} \\
\text { critical } \\
\text { value }\end{array}$ & $\begin{array}{c}\text { ADF } \\
\text { statistics }\end{array}$ & $\begin{array}{c}\mathbf{1 \%} \\
\text { critical } \\
\text { value }\end{array}$ & $\begin{array}{c}\mathbf{5 \%} \\
\text { critical } \\
\text { value }\end{array}$ & $\begin{array}{c}\text { Order of } \\
\text { integration }\end{array}$ \\
\hline GDP & 3.116657 & -3.959148 & -3.081002 & -3.361895 & -3.831511 & -3.029970 & $\mathrm{I}(1)$ \\
\hline PPT & -1.635666 & -3.808546 & -3.020686 & -4.052183 & -3.959148 & -3.081002 & $\mathrm{I}(1)$ \\
\hline CIT & 2.947505 & 2.947505 & -3.020686 & -2.695063 & -3.831511 & -3.029970 & $\mathrm{I}(1)$ \\
\hline VAT & -3.486317 & -3.831511 & -3.029970 & -0.192496 & -3.831511 & -3.029970 & $\mathrm{I}(1)$ \\
\hline
\end{tabular}

\subsection{Unit Root Test}

As reported in the Table 4.3 all the variables used in the study are not stationary at levels with the absolute estimates of the corresponding Augmented Dickey Fuller (ADF) test less that the critical values at $1 \%$ and $5 \%$ levels respectively. Although these variables after the first difference became stationary, this demonstrates that all the series used in the study are difference stationary. In specific terms the unit root test result revealed that all the series are integrated of order one I(1), thus reflecting that all the variables only retain innovative shock passed on them for a short period of time after which they let it go. Following the confirmation of the variables being integrated of order one $\mathrm{I}(1)$, it stands that there is no equilibrium relationship among the variables in the short run with the presence of unit root in at least one of the variables. However there is likelihood of long run equilibrium relationship among the variable in the condition that they co-integrate. Hence, the need to ascertain the long run relationship using the Johansen co-integration test.

Series: GDP PPT CIT VAT

Table-4.4. Johansen Co-integration Test Result.

\begin{tabular}{c|c|c|c|c}
\hline Eigen Value & $\begin{array}{c}\text { Trace } \\
\text { Statistics }\end{array}$ & 5 Percent Critical Value & Probability & $\begin{array}{c}\text { Hypothesized } \\
\text { No of CE(s) }\end{array}$ \\
\hline 0.858735 & 99.18045 & 63.87610 & 0.0000 & None \\
\hline 0.766551 & 61.99528 & 42.91525 & 0.0002 & At most $1 *$ \\
\hline 0.702392 & 34.35427 & 25.87211 & 0.0035 & At most $2^{*}$ \\
\hline 0.449066 & 11.32667 & 12.51798 & 0.0784 & At most $3 *$ \\
\hline
\end{tabular}

Note: * denotes rejection of the hypothesis at $1 \%$ significance level.

Trace test indicates 6 co-integrating eqn(s) at the 0.05 level.

Dependent Variable: GDP.

\subsection{Co-integration Analysis}

Trace statistics reported in Table 4.4 revealed that there is strong evidence to reject the null hypothesis of no co-integration, in favour of six co-integration equation at $5 \%$ level of significance. This implies that though there is no short run equilibrium relationship between gross domestic product and the set of explanatory variables, there is evidence of equilibrium relationship on the long run. 
Table-4.5. Regression Result.

Series: GDP PPT CIT VAT

\begin{tabular}{c|c|c|c|c}
\hline Variable & Coefficient & Std Error & t-statistics & Prob. \\
\hline C & -1469673. & 2209967. & -0.665020 & 0.5150 \\
\hline PPT & 3.707601 & 3.168105 & 1.170290 & 0.2580 \\
\hline CIT & 55.79390 & 16.11551 & 3.462124 & 0.0030 \\
\hline VAT & 16.04333 & 29.60023 & 0.542000 & 0.5949 \\
\hline Note: R-square $=0.963037$, Adjusted R-square $=0.0 .956515$
\end{tabular}

Estimation result presented in Table 4.5 revealed that the long run petroleum profit tax exerts significant positive impact on gross domestic product, with coefficient estimate of $3.707601(\mathrm{p}=0.5150>0.05)$, company income tax exerts significant positive impact on gross domestic product with coefficient estimate of $55.79390(\mathrm{p}=0.2580>0.05)$ while value added tax insignificant influences positively on gross domestic product with coefficient estimate of 16.04333( $\mathrm{p}=0.5949>0.05)$. Reported R-square statistics stood at 0.963037 which reflect that on the long the combination of the impact of petroleum profit tax, company income tax and value added tax can explain about $96 \%$ of the systematic variation in the country's national income measured in terms of gross domestic product.

Table-4.6. Post Estimation Test.

\begin{tabular}{l|c|c}
\hline \multicolumn{3}{c}{ Linearity Test } \\
\hline Statistics & Values & Probability \\
\hline T-statistic & 4.243623 & 0.0006 \\
\hline F-statistic & 18.00834 & 0.0006 \\
\hline Likelihood Ratio & 15.83436 & 0.0001 \\
\hline Statistics & Values & Probability \\
\hline Jarque-Bera Stat & 23.56842 & 0.0008 \\
\hline Statistics & Values & Probability \\
\hline F-statistic Correlation LM Test & 0.0520 \\
\hline Statistics Heteroscedasticity Test \\
\hline F-statistic & Values & Probability \\
\hline
\end{tabular}

Result of Ramsey test presented in Table 4.6 report three statistics including t-statistics, f-statistics and likelihood ratio statistic, alongside their respective probability values. Specifically Table 4.6 reported tstatistics of 4.243623, f-statistics of 18.00834 and likelihood ratio of 15.83426 alongside respective probability values of $0.0006,0.0006$ and 0.0001 . Hence overview of the reported statistics and their corresponding probability values revealed that there is no enough evidence to reject the null hypothesis that the model is correctly specified. The Jarque-bera statistics and probability values of the estimated models, stood at 23.56842 and 0.0008. The result revealed that there is no enough evidence to reject the null that the error term of the estimated model is normally distributed, given the probability value that is greater than 0.05 , thus confirming that the error term normally distributed. Additionally, Breusch-Godfrey serial correlation LM test result presented in Table 4.6 revealed f-statistics and probability values of 3.624645 and 0.0520 respectively. The statistics showed that there is no evidence to reject the null hypothesis of no serial correlation between successive values of error terms of the estimated models. Hence there is no problem of serial autocorrelation in the estimated models. Lastly, the table 4.7 report f-statistics and probability values of 1.416072 and 0.2726 . Given the probability of the reported f-statistics it stands that there is no evidence to reject the null hypothesis of constant variance of the error term (homoscedasticity). Hence the test confirmed that there is no problem of heteroscedasticity in the error term of the estimated models.

\section{Summary of Findings}

Investigation carried out to examine the nexus between tax revenue (proxied by petroleum profit tax, company income tax and value added tax) and economic growth in Nigeria measured in terms of gross domestic product, discovered the following. Long run estimation carried out in the study indicated that the long run revenue from petroleum profit tax exerts a noticeable positive impact on gross domestic product, with coefficient estimates of $3.707601(\mathrm{p}=0.5150>0.05)$, company income tax also exerts a significant positive effect on gross domestic product with coefficient estimate of 55.79390 ( $\mathrm{p}=0.2580>0.05)$, while the impact of value added tax on gross domestic product is positive and significant, with coefficient estimate of 16.04333 $(p=0.5949>0.05)$. The result indicated that tax revenue expressed in terms of petroleum profit tax, company income tax and value added tax will on the long and short run influence the level of national output. 


\section{Conclusion and Recommendations}

Premise on the discoveries of this study, it is therefore concluded that tax revenue affects significantly economic growth in Nigeria. Petroleum profit tax has a significant impact on economic growth, corporation taxes have an increased significant influence on economic growth and value added also exerts a significant impact on economic growth both in the long and short run. Therefore, government should make efficacious the tax system of the country so as to curb practices that hampers the effectiveness of the system to generate the required revenue to cause a change in the growth of the economy. Also, the government should modify the institutional arrangement so as to aid a model for best practices of industries in the country, so as to ensure an increased industrial output in the country at the barest cost.

\section{References}

Abomaye-Nimenibo, W. A. S., Michael, J. E. M., \& Friday, H. C. (2018). An emperical analysis of tax revenue and economic growth in Nigeria from 1980 to 2015. Global Journal of Human-Social Science, Political Science, 18(3), 9-40.

Abubakar, G. (2008). Guide to Nigerian taxation. Ikeja: All Group Nigeria Limited Publishers.

Adegbie, F. F., \& Fakile, A. S. (2011). Company income tax and Nigeria economic development. European Journal of Social Sciences, 22(2), 309-320.

Adereti, S. A., Sanni, M. R., \& Adesina, J. A. (2011). Value added tax and economic growth of Nigeria. European Journal of Humanities and Social Sciences, 1O(1), 456-471.

Adesola, S. M. (2004). Income tax law and administration in Nigeria. Academy of Management Journal, 42(16), 51-62.

Adeyeye, G. B. (2004). An overview of personal income tax in Nigeria: A case study of Lagos State. Global Journal of Accounting, 1(2), 15-33.

Anyanwu, J., \& Anyanfo, O. (1996). Personal income tax and economic growth. Onitsha: Joeanee Publishers.

Appah, E. (2004). Principles and practice of Nigerian taxation. ort Harcourt: Ezevlin Mint. Printers, P.

Appah, E. (2010). The problems of tax planning and administration in Nigeria: The federal and state governments experience. Asian Journal of Research in Banking and Finance, 4(12), 1-14.

Ayodele, O. (2006). Tax policy reform in West Africa: A case study of Nigeria. Journal of Accounting, Auditing and Finance, $17(29), 26-38$

Ayua, I. A. (1996). The Nigeria tax law. Ibadan: Spectrum Law Publishing.

Central Bank of Nigeria. (2014). Statistical bulletin. Retrieved from http://www.cbn.gov.ng/.

Desai, M. A., Foley, C. F., \& Hines, J. R. (2004). Foreign direct investment in a world of multiple tax. Journal of Public Economics, 88(1), 27-44.

Dwivedi, D. N. (2004). Management economics (6th ed.). London: Matins Press Inc.

Edame, G. E., \& Okoi, W. W. (2014). The impact of taxation on investment and economic development in Nigeria. Academic Journal of Interdisciplinary Studies, 3(4), 209-2 18.

Edemode, J. (2009). Towards a people- focused tax system in Nigeria. International Journal of Accountancy, $16(3), 153-169$.

Egbunike, F. C., Emudainohwo, O. B., \& Gunardi, A. (2018). Tax revenue and economic growth: A study of Nigeria and Ghana. Journal of Economics, 7(2), 213-220.

EIA, U. (2015). Electric power annual 2012

Enahoro, J., \& Olabisi, J. (2012). Tax administration and revenue generation of Lagos State. Research Journal of Finance and Accounting, 28(13), 110-124.

Garde, M. (2004). A model of tax administration reform. The Accounting Review, 33(59), $216-227$.

Goode, R. (1984). Governement finance in developing countries. Washington D.C: The Brookings Institute.

Igbasan, E. (2017). Tax revenue and economic growth of Nigeria (1981-2015). An Unpublished Thesis, Babcock University, Ogun State.

Inglehart, R., Foa, R., Peterson, C., \& Welzel, C. (2002). Deterrence and morale in taxation: An empirical analysis. CESifo Working Paper No. 760, August 2002.

Iweala, N. O. (2013). The federal government is losing over N80 billion monthly from registered companies that refuse to pay taxes. Nigeria Newsdesk.

Karumba, A. K. (2016). Impact of taxation on economic growth in Kenya (1975-2014). An Unpublished Thesis, University of Nairobi, Kenya.

Kiabel, B. D., \& Nwokah, N. G. (2009). Boosting revenue generation by State Governments in Nigeria: The tax consultants opinion revisited. European Journal of Social Sciences, 8(4), 34-48.

Lerato, R. (2016). The relationship between tax and economic growth: A South African perspective. An Unpublished Thesis, University of Cape Town, South Africa.

Leyira, C., Chukwuma, E., \& Asian, U. (2012). Tax system in Nigeria: Challenges and the way forward. Research Journal of Finance and Accounting, 3(9), 51-65.

Mansfield, C. (1998). Tax administration in developing countries. International Monetary Fund Staff Papers, 35(1), $181-197$.

Maqbool, H. S., Shahzad, A., \& Nisae, A. (2016). Taxes and economic growth: An empirical analysis of Pakistan. European Journal of Business and Social Sciences, 5(2), 16-29.

Miller, A., \& Oats, L. (2006). Principles of international taxation. London, U.K.: Tottel Publishing.

Musgrave, R. A. (1989). Income taxation and international mobility: MIT Press.

Naiyeju, J. K. (2010). Nigerian speaks on taxation: A tool for social change administration in Nigeria and the issue of tax refund. Journal of Accounting, Auditing and Finance, 41(25), 35-47.

National Bureau of Statistics. (2014). Sector statistics. Retrieved from www.nigerianstat.gov.ng/.

National Tax Policy. (2008). National tax policy: Handbook by Federal Ministry of Finance. Ojo, S., (2008). Fundamental Principles of Nigerian Tax Lagos: Sagribra Tax Publications.

Nkhalamo, J. C., \& Sheefeni, J. P. S. (2017). Tax and economic growth in Namibia. European Journal of Business, Economics and Accountancy, 5(2), 52-61. 
Odusola, A. F. (2006). Tax policy reforms in Nigeria. A Research work of United Nations University-World Institute for Development Economies Research, Research Paper, No. O3, 1-45.

Ofishe, O. W. (2015). The impact of value added tax on economic growth in Nigeria (1994 - 2012). Research Journal of Finance and Accounting, 6(23), 34-46.

Ogundana, M. O., Ogundana, M. O., Ogundana, M. O., Ibidunni, S. I., \& Adetoyinbo, A. A. (2017). Impact of direct and indirect tax on the Nigerian economic growth. Binus Business Review, 8(3), 215-220.

Ojong, C. M., Anthony, O., \& Arikpo, O. F. (2016). The impact of tax revenue on economic growth: Evidence from Nigeria. Journal of Economics and Finance,, 7(1), 32-38.

Okoli, M. N., Njoku, C. O., \& Kaka, G. N. (2014). Taxation and economic growth in Nigeria; a granger causality approach. International Journal of Research in Management, Science छ Technology, 2(3), 64-80.

Ola, C. S. (2001). Income tax law and practice in Nigeria. Ibadan: Heinemann Educational Books Nigeria Plc.

Olashore, O. (1999). Strategies for economic revival. The Guardian Newspaper.

Onakoya, A. B., \& Afintinni, O. I. (2016). Taxation and economic growth in Nigeria. Asian Journal of Economic Modelling, 4(4), 199-210.

Onaolapo, A. A., Fasina, H. T., \& Adegbite, T. A. (2013). The analysis of the effect of petroleum profit tax on Nigerian economy. Asian Journal of Humanities and Social Sciences, 1(1), 25-36.

Salizi, B. K., \& Squire, A. I. (1988). Analysis of structural shifts of government revenue in Nigeria. The Nigerian Journal of Economic and Social Studies, 30(2), 13-28.

Solow, R. M. (1956). A contribution to the theory of economic growth. The Quarterly Jorunal of Economics, 70(1), 65-94

Swan, T. W. (1956). Economic growth and capital accumulation. Economic Record, 32(3), 334-361.

Todaro, M. P., \& Smith, S. C. (2006). Economic development. New Jersey: Pearson Addison Wesley.

Tosun, S., \& Abizadeh, S. (2005). Economic growth and tax components: An analysis of tax changes in OECD. Applied Economics, 35(19), 2251-2263.

Unegbu, A. O., \& Irefin, D. (2011). Impact of VAT on economic development of emerging nations. Human Capacity Assessment of Nigeria's Local Government (Unpublished).

Uremadu, S. O., \& Ndulue, J. C. (2011). A review of private sector tax revenue generation at local government level: Evidence from Nigeria. Journal of Public Administration and Policy Research, 3(6), 174-183.

Wikipedia - The Free Encyclopedia. (2011). Retrieved from https://en.wikipedia.org/wiki/Economy_of_Nigeria.

World Bank. (2000). East Asia: Recovery and beyond. Washington, D.C: The World Bank.

Worlu, C. N., \& Emeka, N. (2012). Tax revenue and economic development in Nigeria: A macroeconometric approach academic. Journal of Interdisciplinary Studies, 21(46), 121-139.

Yahaya, K. A., \& Bakare, T. O. (2018). Effect of petroleum profit tax and companies income tax on economic growth in Nigeria. Journal of Public Administration, Finance and Law, 13(1), 100-12 1. 